\title{
Milczenie organów administracji jako instytucja materialnego i procesowego prawa administracyjnego
}

\section{Wprowadzenie}

Instytucja milczenia administracji publicznej to zagadnienie o doniosłym znaczeniu prawnym i praktycznym dla stron postępowania administracyjnego. Jest to problematyka uregulowana w sposób bardzo zróżnicowany w państwach członkowskich Unii Europejskiej, wciąż wzbudzająca wiele polemicznych dyskusji naukowych, zwłaszcza w zakresie jej klasyfikacji w ramach prawnych form działania organów administracji publicznej.

Milczenie organu administracji publicznej w polskiej procedurze administracyjnej zostało uregulowane mocą Ustawy z dnia 7 kwietnia 2017 r. o zmianie ustawy - Kodeks postępowania administracyjnego oraz niektórych innych ustaw ${ }^{1} \mathrm{w}$ rozdziale 8 a działu II. Nie jest to jednak instytucja nowa, w Polsce funkcjonowała już w wieku XIX w charakterze instytucji materialnoprawnej. Jednakże ujęciu milczenia administracji jako instytucji wyłącznie materialnoprawnej przeczy jej główny cel, którym jest przeciwdziałanie opieszałości organu w postępowaniu administracyjnym. Obowiązywanie regulacji milczenia organu administracyjnego stanowi element gwarantujący realizację zasady szybkości i prostoty postępowania $\mathrm{z}$ art. 12 k.p.a.

$\mathrm{W}$ polskim porządku prawnym milczenie administracji wywołuje skutki prawne, o ile przepis ustawy prawa materialnego tak stanowi. Tak

${ }^{1}$ Dz.U. poz. 935, dalej „k.p.a." lub „Kodeks”. 
pojmowane milczenie jest instytucją prawną odrębną od zaniechania, które rozumiane jest jako bezczynność organu. Bezczynność administracji publicznej polega na niepodejmowaniu działań przez organ w sytuacji, gdy norma prawna tego od niego wymaga. Odrębnym od milczenia administracji publicznej wywołującego skutki prawne zjawiskiem prawnym jest przewlekłość postępowania. Polega ona na podejmowaniu przez organ czynności, które jednak w sposób bezzasadny prowadzą do przedłużenia terminu załatwienia sprawy. Ustawodawca polski przyjmuję zasadę, że milczenie administracji publicznej stanowi fikcję decyzji pozytywnej ${ }^{2}$, podczas gdy w wielu państwach europejskich fikcja milczenia administracji publicznej zrównana jest $z$ decyzją negatywną bądź z bezczynnością organu, co wymaga szczególnej ochrony jednostki przed tą formą zaniechania administracji ${ }^{3}$.

Pomimo że problematyka milczenia organu administracji publicznej jest ważkim zagadnieniem, wciąż liczba opracowań tego tematu jest

${ }^{2}$ A. Gronkiewicz wskazuje jednak, że regulacje obowiązujące w przepisach szczególnych prawa administracyjnego ukazuja, iż trudno jest jednoznacznie wskazać, że w przypadku milczącej zgody jest to zawsze fikcja decyzji pozytywnej, są to bowiem postępowania niemające jurysdykcyjnego charakteru, ale jedynie charakter techniczny bądź mieszany, co powoduje, że jest to fikcja podjęcia czynności materialno-technicznej, zob. A. Gronkiewicz, Milczace załatwienie sprawy jako nowa instytucja postępowania administracyjnego, $\mathrm{w}$ : Nowe instytucje procesowe w postępowaniu administracyjnym w świetle nowelizacji Kodeksu postępowania administracyjnego z dnia 7 kwietnia 2017, pod red. A. Gronkiewicz, A. Ziółkowskiej, Katowice 2017, s. 231.

${ }^{3}$ We Francji art. 21 ustawy nr 200-321 z dnia 12 IV 2000 r. w sprawie praw obywateli $\mathrm{w}$ ich stosunkach z administracją (Loi n ${ }^{\circ}$ 2000-321 du 12 avril 2000 relative aux droits des citoyens dans leurs relations avec les administrations) stanowi, że z zastrzeżeniem przypadków, w których decyzje akceptujące oparte zostały na milczącej zgodzie, milczenie właściwego organu przez okres dwóch miesięcy w sprawie administracyjnej wszczętej na wniosek strony jest równoznaczne z decyzją odmowną. We Włoszech system prawny rozróżnia milczenie administracji w sensie pozytywnym (aprobata milcząca) oraz w sensie negatywnym (odmowa, odrzucenie wniosku strony) oraz milczenie rozumiane jako bezczynność, z którą ustawa nie wiąże żadnego skutku prawnego - tak stanowi art. 2 ust. 1, 5 i 20 „ustawy nr 241/1990 o postępowaniu administracyjnym z dnia 18 VIII 1990 r. Natomiast w Niemczech niewydanie aktu przez administrację jest zjawiskiem negatywnym $\mathrm{i}$ jest to zjawisko sprzeczne z prawem, o czym stanowi $\S 113$ ust. 5 ustawy z dnia 21 I 1960 r. o ustroju sądów administracyjnych i postępowaniu przed nimi (VwGO). W Hiszpanii ustawa stanowi, że w niektórych przypadkach milczenie administracyjne jest pozytywne, co oznacza, że wniosek jest rozpoznany zgodnie z żądaniem. Jednak zasadą jest, że milczenie administracji jest równoznaczne z decyzją odmowną, przy czym obywatel wie, że po upływie terminu do wydania decyzji, może odwołać się od odmowy. Regulacja ta zawarta została w art. 43 ustawy nr 30/1992 z dnia 26 XI 1992 r. w sprawie systemu prawnego administracji publicznej i wspólnej procedury administracyjnej. 
niewystarczająca. Najszersze ujęcie monograficzne dotykające problematyki milczenia administracji publicznej ${ }^{4}$ powstało przed wejściem w życie regulacji proceduralnej tej instytucji do polskiego k.p.a.

Na gruncie problematyki milczenia administracji przeanalizować należy następujące problemy badawcze.

Od wielu lat trwa dyskurs w doktrynie dotyczący różnych definicji milczenia organów administracji publicznej. Taki stan powoduje przeciwstawne interpretacje norm prawa materialnego stanowiących o skutkach prawnych milczenia administracji, a także prowadzi do braku spójności poglądów co do klasyfikacji milczenia organów administracji publicznej.

W artykule podjęto próbę odpowiedzi na pytanie, jak zdefiniować milczenie administracji. Szukać jej należy w przepisach prawa materialnego, albowiem zgodnie z uzasadnieniem do nowelizacji k.p.a. instytucja milczącego załatwienia sprawy w Kodeksie postępowania administracyjnego ma charakter wyłącznie ramowy. Podstawę prawną do jej zastosowania stanowią zaś przepisy prawa materialnego ${ }^{5}$.

Postawić można także pytanie, czy regulacja kodeksowa, mająca dość ogólny zakres normowania, pozwala na zakwalifikowanie milczenia organu administracji w ramach utartych już prawnych form działania administracji. Od wielu lat w tym przedmiocie stawiane są różnorodne tezy. W ocenie niektórych przedstawicieli doktryny milczenie organu administracji publicznej stanowi swoista, nietypową formę działania organu administracji ${ }^{6}$. Inni naukowcy podnosza, że jest to typowa wręcz tradycyjna/klasyczna forma działania administracji, która może być zaliczona do czynności materialno-technicznych ${ }^{7}$. Powyżej przytoczone głosy nie są jedynymi poglądami na klasyfikację milczenia administracji w doktrynie polskiej. Szerzej zostaną one jednak zaprezentowane w dalszej części artykułu. W ramach tego problemu należy pochylić się nie tylko nad kwalifikacją samego milczenia organu administracji, ale także nad czynnością w postaci potwierdzenia milczącego załatwienia sprawy, wydawanego stronie na jej wniosek.

\footnotetext{
${ }^{4}$ Najszerszym opracowaniem jest monografia P. Dobosza, Milczenie i bezczynność w prawie administracyjnym, Kraków 2011.

${ }^{5}$ Uzasadnienie do ustawy o zmianie ustawy - Kodeks postępowania administracyjnego oraz niektórych innych ustaw, druk sejmowy 1183/VIII kadencja, s. 45, http:// sejm.gov.pl/Sejm8.nsf/druk.xsp?nr=1183 (dostęp: 15 IV 2018).

${ }^{6}$ J. Zimmermann, Prawo administracyjne, Warszawa 2006, s. 359.

${ }^{7}$ A. Ostrowska, J. Stelmasiak, Rejestracja budowy (przyjęcie zgłoszenia budowy) jako prawna forma działania administracji - uwagi de lege ferenda, w: Kodyfikacja postepowania administracyjnego na 50-lecie K.P.A., pod red. J. Niczyporuka, Lublin 2010, s. 601.
} 
W dalszej kolejności zastanowić się należy, czy regulacja kodeksowa milczenia administracji publicznej, po roku obowiązywania, przyczyniła się do zwiększenia efektywności stosowania tej formy działania przez organy administracji publicznej. Rozważania te będą dotyczyły wybranego przykładu milczenia organów administracji architektoniczno-budowlanej. Jawią się na tym tle takie pytania, jak: Czy instytucja ta jest częściej wykorzystywana w praktyce, czy zwiększone jej zastosowanie nie godzi w podstawowe gwarancje proceduralne dla administrowanych? Czy aprobowanie przez ustawodawcę milczenia administracji nie stanowi przyzwolenia na mechanizm, który jedynie pozornie polepsza sytuację prawną podmiotów, wobec których milczenie wywołuje skutki prawne? Te oraz wiele innych pytań można postawić, analizując regulacje proceduralne i materialnoprawne milczenia organów administracji, które wywołują skutki prawne.

W k.p.a. uregulowano dwie postaci milczącego załatwienia sprawy przez organ administracji publicznej, tj. milczące zakończenie postępowania w art. 122a § 2 pkt 1 k.p.a. (tzw. instytucję bierną) oraz milczącą zgodę w art. 122a § 2 pkt 2 k.p.a. (tzw. przejaw aktywnego milczenia). Dotąd ustawodawca posługiwał się różnymi sformułowaniami na określenie wystąpienia kwalifikowanego skutku milczenia organu odpowiadającego fikcji pozytywnego rozstrzygnięcia sprawy, dlatego też podjęto decyzję, by dokonać rozróżnienia dwóch form milczenia. Za cel regulacji milczenia jako sposobu załatwienia sprawy, jak również milczącej zgody, ustawodawca postawił sobie przyspieszenie i uproszczenie postępowania administracyjnego, a także zmniejszenie kosztów administrowania.

Polska jako członek Unii Europejskiej, w ramach dostosowania prawa krajowego do założeń i postanowień dyrektywy 2006/123/WE Parlamentu Europejskiego i Rady z dnia 12 grudnia 2006 r. dotyczącej usług na rynku wewnętrznym ${ }^{8}$, stanowiącej w art. 5 o upraszczaniu procedur administracyjnych m.in. poprzez wprowadzenie milczącego załatwiania spraw, rozbudowała regulację proceduralną tej instytucji prawnej. Dyrektywa ta odnosi się wyłącznie do przedsiębiorstw usługowych i rozwijania nowej przedsiębiorczości, jednakże katalog spraw, które mogą zostać załatwione za pomocą milczenia sprawczego, powinien być o wiele szerszy i dotyczyć spraw niezwiązanych z prowadzeniem działalności gospodarczej.

${ }^{8}$ Dyrektywa 2006/123/WE Parlamentu Europejskiego i Rady z dnia 12 XII 2006 r. dotycząca usług na rynku wewnętrznym (Dz.Urz. UE L 376 z 27 XII 2006 r., s. 36). 
Istotnym powodem podjęcia badań nad instytucją milczenia organu administracyjnego jest także konieczność rozważenia, czy instytucja ta w niektórych przypadkach nie ogranicza ochrony administrowanych, w stosunku do których milczenie organu wywołuje skutki prawne, bądź interesów osób trzecich, których sytuacji prawnej dotyczą skutki milczenia. Ustawodawca przyjął zasadę, że rozstrzygnięcie milczące nie podlega zaskarżeniu na ogólnych zasadach k.p.a. ani w drodze skargi do sądu administracyjnego. $W$ tym przypadku nie mamy bowiem do czynienia z decyzją ani też z innym aktem lub czynnościa, która mogłaby stać się przedmiotem postępowania odwoławczego albo kontroli sądu administracyjnego.

\section{Milczenie jako szczególna prawna forma działania administracji}

Milczenie organu administracji postrzegane musi być w kategoriach zjawiska ze sfery jurysdykcyjnej. Jednocześnie jednak jest to kategoria prawa materialnego. Po nowelizacji k.p.a. aktualne pozostaje twierdzenie, że fikcja pozytywnego rozstrzygnięcia sprawy jest konstrukcją materialnego prawa administracyjnego, normowaną przepisami zarówno proceduralnymi, jak i materialnoprawnymi ${ }^{9}$.

Milczenie administracji nie zostało zdefiniowane w przepisach rozdziału 8a działu II k.p.a. W art. 122a k.p.a. dokonano jedynie podziału milczenia organu administracji na dwie kategorie pojęciowe. Jednakże brakuje $\mathrm{w}$ dalszym ciągu regulacji samej definicji pojęcia milczenia, co powoduje, że zmiany wprowadzone do Kodeksu trudno uznać za rewolucyjne ${ }^{10}$. Definicje milczenia administracyjnego formułowane są jedynie w doktrynie. P. Dobosz wskazał, że milczenie administracji można rozumieć jako przejaw woli organu administracji publicznej (formę działania administracji), z którym ustawa łączy przede wszystkim materialne albo odpowiednio ustrojowe skutki prawne dopuszczone przez wyraźne postanowienia materialnoprawne, ustrojowe i proceduralne. Autor ten podaje także definicję alternatywną milczenia, określając je

${ }^{9}$ M. Kruś, E. Szewczyk, M. Szewczyk, Przyjęcie zgłoszenia robót budowlanych w kontekście fikcji pozytywnego rozstrzygnięcia sprawy, w: Dziesięć lat polskich doświadczeń w Unii Europejskiej: problemy prawnoadministracyjne, pod red. J. Sługockiego, Warszawa 2014, s. 177.

${ }_{10} \mathrm{~J}$. Piecha, Milczace załatwienie sprawy w Kodeksie postepowania administracyjnego rewolucja czy nie?, "Radca Prawny ZN” 2017, nr 2, s. 79-98. 
jako zdarzenie prawne polegające na określonym ustawą zachowaniu się organu administracji publicznej polegającym na bierności (niewyrażeniu sprzeciwu, stanowiska, opinii, niewydaniu decyzji w określonym czasie), z którą ustawa wiąże skutki prawne ${ }^{11}$.

Najczęściej w doktrynie wskazuje się, że milczenie organu administracji stanowi formę prawną działania administracji tradycyjną bądź specyficzną. Do czasu wprowadzenia do k.p.a. rozdziału 8a działu II posługiwano się zróżnicowanym nazewnictwem zaniechania administracji, z którym ustawodawca wiązał skutki prawne, takim jak: „milczenie sprawcze organu"12, "milczenie administracyjne ${ }^{\prime 13}$, "milczenie prawne ${ }^{\prime 14}$. Wprowadzenie rozdziału 8a zatytułowanego "Milczące załatwienie sprawy" porządkuje chaos terminologiczny.

Przyjmując koncepcję formy prawnej działania administracji dla milczącego załatwienia sprawy, zastanowić się należy nad tym, czym jest z prawnego punktu widzenia: (1) niewniesienie przez organ administracji sprzeciwu $\mathrm{w}$ określonym prawem materialnym terminie liczonym od dnia doręczenia przez stronę zamiaru powzięcia określonej prawnie aktywności, (2) niewydanie decyzji lub postanowienia kończącego postępowanie $\mathrm{w}$ sprawie $\mathrm{w}$ wyznaczonym przez prawo terminie, z którego upływem ustawodawca wiąże skutek w postaci pozytywnego zakończenia sprawy. Zaniechanie podjęcia przez organ administracji publicznej działania jest przejawem świadomej decyzji organu, a zatem świadomym brakiem działania, czyli formą zachowania się organu administracji publicznej. Milczenie organu administracji wiąże się z niepodejmowaniem przez organ form działania o charakterze publicznoprawnym. W konkretnym kontekście sytuacyjnym z milczeniem organu polegającym na nierealizowaniu określonej formy działania wiąże się powstanie pewnych skutków materialnoprawnych. Rodzi się jednak pytanie, czy jest to forma tradycyjna, czy też szczególna? A jeśli można było mówić o niej jako o formie szczególnej - przed dodaniem rozdziału 8a do k.p.a. - to czy po tej nowelizacji świadome zaniechanie organu administracji publicznej może zostać zaliczone do tradycyjnych form działania administracji?

${ }^{11}$ P. Dobosz, Milczenie i bezczynność..., s. 349.

12 Tak nazywa instytucję M. Miłosz, Bezczynność organu administracji publicznej w postępowaniu administracyjnym, Warszawa 2011, s. 176.

13 A. Kubiak, Fikcja pozytywnego rozstrzygnięcia w prawie administracyjnym, "Państwo i Prawo" 2009, z. 11, s. 43.

${ }^{14}$ P. Dobosz, Milczenie i bezczynność..., s. 350. 
Przedstawiciele nurtu tradycyjnej formy działania administracji wskazuja, że jest to czynność faktyczna w sferze zewnętrznej o charakterze materialno-technicznym ${ }^{15}$. Taką klasyfikację można zastosować do samego zaświadczenia organu stanowiącego potwierdzenie prawnie skutecznej bierności administracji, w przypadku jednak samego milczącego załatwienia sprawy jest to pewien akt bierności administracji wywołujący bezpośrednio skutki prawne.

W ramach nurtu, zgodnie z którym milczenie administracji jest specjalną prawną formą jej działania, wskazuje się, że milczenie jest aktem konkludentnym, który polega na tym, iż z upływem wyznaczonego terminu do zakończenia postępowania bądź z brakiem wniesienia sprzeciwu w terminie ustawodawca wiąże przewidziane prawem skutki. Jest to wyrażenie woli przez organ, czyli dorozumiany akt administracyjny będący podstawą do nawiązania stosunku administracyjnoprawnego ${ }^{16}$. Pogląd ten należy uznać za trafny.

Ciekawe są także poglądy, które nie przeczą powyższym rozważaniom, jednak wskazuja, że milczenie administracji publicznej jest formą prawną działania wyłamującą się z tradycyjnej klasyfikacji, ponieważ jest przyczyną skutku prawnego określonego dyspozycją normy prawnej ${ }^{17}$. Milczenie nie jest źródłem skutku prawnego, lecz jego przyczyna, stanowi bowiem element stanu faktycznego, z którym prawo materialne wiąże określony skutek prawny. Powstrzymanie się organu od podjęcia aktu administracyjnego jest rozumiane przez tych autorów jako element stanu faktycznego, z którym norma wiąże skutki prawne. Takie rozumienie milczącego załatwienia sprawy polegającego na pozostawieniu jednostce określenia jej uprawnień lub obowiązków publicznoprawnych na skutek dokonania określonej czynności prawnej (np. zgłoszenia, rejestracji) oraz przyznaniu organowi kompetencji do kontroli zgodności tej czynności z prawem w ciągu określonego ustawą terminu potwierdza swoisty charakter tej instytucji niebędącej de facto czynnością prawną, ale także niebędącej czynnością materialno-techniczna, lecz zdarzeniem prawnym, z którym norma wiąże skutek prawny.

${ }^{15}$ A. Kubiak, op. cit., s. 45.

${ }^{16}$ Tak też P. Dobosz, Bezczynność administracji publicznej w postępowaniu administracyjnym, w: Kodyfikacja..., s. 148.

${ }^{17}$ M. Masternak, M. Szalewska, "Milczenie" organu administracji publicznej - między prakseologia a teoria prawnych form działania administracji, w: Wspótzależność dyscyplin badawczych w sferze administracji publicznej, pod red. S. Wrzoska, M. Domagały, J. Izdebskiego, T. Stanisławskiego, Warszawa 2010, s. 491. 
Nieco inaczej problematykę milczenia organu administracji ujmował T. Bąkowski. Wskazywał on, że milczenie nie jest rezultatem procesu stosowania normy prawa administracyjnego, nie ma bowiem zmaterializowanego rezultatu stosowania normy, a w konsekwencji nie może być ono przedmiotem kontroli sądowej ${ }^{18}$. Podsumowując, autor ten wskazał, że milczenie stanowi zdarzenie prawne, z którym norma ustawy prawa materialnego wiąże skutek prawny. Norma stanowiąca o kompetencji organu do milczenia wywołującego skutek prawny kształtuje prawną sytuację adresatów.

Interesującą koncepcję milczenia przedstawiła także B. Adamiak, wskazując, że milczenie stanowi swoistą postać władztwa publicznoprawnego, które oznacza przyznanie skuteczności, ocenianej jako zgodnej z przepisami prawa, czynności jednostki podjętej na skutek milczenia administracji publicznej. Autorka ta wskazuje na trzy zachowania organów administracyjnych kształtujących sytuację prawną podmiotu administrowanego, tj. milczenie, wydanie decyzji oraz czynności materialno-techniczne. Milczenie gwarantuje trwałość czynności materialnoprawnej jednostki, która nie podlega weryfika$\mathrm{cji}^{19}$. Autorka w dalszych swoich rozważaniach wyróżnia jednak dwie konstrukcje czynności organów administracji publicznej. Po pierwsze, kiedy czynność jednostki kształtuje bezpośrednio jej prawa i obowiązki pod warunkiem niepodjęcia przez organ władczej ingerencji. Po drugie, kiedy to czynność materialnoprawna jednostki wymaga dla ukształtowania jej prawa podjęcia czynności prawnej przez organ bądź czynności faktycznej o charakterze materialno-technicznym. Tak przedstawione koncepcje klasyfikacji prawnych form działania administracji ukazuja, że B. Adamiak także zalicza milczenie administracji do specyficznych (nietypowych) prawnych form działania organów administracji publicznej, które nie są czynnościami prawnymi, ani też faktycznymi.

Dotąd w doktrynie wyróżniały się dwa nurty poglądów. Pierwszy z nich ujmował milczenie organu administracji jako klasyczną formę działania administracji mieszczącą się w obrębie dotychczasowej klasyfikacji jako czynność faktyczną materialnoprawną bądź akt

18 T. Bąkowski, W sprawie milczącej zgody organu, „Państwo i Prawo” 2010, z. 3, s. 108.

${ }^{19}$ B. Adamiak, Czynności prawne jednostki a władztwo administracyjne, w: Wspótczesne zagadnienia prawa i procedury administracyjnej. Ksiega jubileuszowa dedykowana Profesorowi Jackowi M. Langowi, pod red. M. Wierzbowskiego, J. Jagielskiego, A. Wiktorowskiej, E. Stefańskiej, Warszawa 2009, s. 27. 
administracyjny konkludentny ${ }^{20}$. Zgodnie z drugim nurtem milczenie stanowi specyficzną formę działania administracji publicznej. Zachowanie polegające na milczeniu jest zdarzeniem prawnym, które z mocy prawa wywołuje skutki prawne ${ }^{21}$. Dodać do tego należy, że owo zdarzenie prawne pociągające za sobą powstanie, zmianę lub rozwiązanie stosunku administracyjnoprawnego jest zależne od woli organu administracji publicznej, dlatego też nazywać możemy je działaniem. Takie zdarzenie stanowi zatem regulowane prawem materialnym i proceduralnym działanie organu administracji publicznej.

Przyjęcie jednej z tych klasyfikacji determinuje przyjęcie określonej koncepcji wywoływania skutków prawnych, a także wiąże się w konsekwencji z przyjęciem różnych gwarancji w stosowaniu milczenia przez administrację publiczną. W przypadku koncepcji milczenia jako tradycyjnej prawnej formy działania to elementy woli miałyby kształtować skutek prawny. Jeśli byłby to akt konkludentny, to sam ten akt wywoływałby skutki prawne, w przypadku zaś koncepcji czynności faktycznej skutki prawne powstałyby niejako dodatkowo, obok zmian w otaczającej rzeczywistości. Natomiast w stosunku do koncepcji milczenia jako zdarzenia prawnego P. Dobosz wyraził wątpliwość, że koncepcja taka automatyzuje i odhumanizowywuje zaniechanie administracji, zbliża je do bezczynności, czyli negatywnej bierności organów ${ }^{22}$, a wręcz daje przyzwolenie administracji na bierność, co w demokratycznym państwie prawa jest trudne do zaakceptowania, zwłaszcza przyjmując koncepcję dobrej administracji ${ }^{23}$.

Biorąc to pod uwagę, należy rozważyć model regulacji prawnej milczenia zawarty w Kodeksie postępowania administracyjnego i na tle tej ramowej regulacji prawnej podjąć próbę zdefiniowania milczenia administracyjnego i jego klasyfikacji w ramach form działania administracji.

W uzasadnieniu do ustawy o zmianie Kodeksu postępowania administracyjnego i innych ustaw z dnia 7 kwietnia 2017 r. wskazano, że „[m]ilczące załatwienie sprawy polega na wprowadzeniu pewnego rodzaju fikcji pozytywnego załatwienia sprawy przez organ administracji publicznej - «milczenie» organu po upływie ustawowego terminu na załatwienie sprawy uznaje się za jej załatwienie w sposób

\footnotetext{
${ }^{20}$ P. Dobosz, Bezczynność administracji publicznej..., s. 148.

${ }^{21}$ T. Bąkowski, op. cit., s. 109.

22 P. Dobosz, Milczenie i bezczynność..., s. 355-356.

${ }^{23}$ M. Princ, Standardy dobrej administracji w prawie administracyjnym, Poznań 2017, s. 78.
} 
uwzględniający w całości żądanie strony" ${ }^{\prime 24}$. Milczącego załatwienia sprawy można uniknąć tylko poprzez wydanie wymaganego przepisami prawa aktu administracyjnego, np. decyzji. Z kolei milcząca zgoda, wyrażająca się w braku skorzystania przez organ z możliwości wniesienia sprzeciwu w określonym terminie, stanowić ma przejaw upraszczania postępowania ${ }^{25}$. Niewniesienie sprzeciwu stanowić ma świadomy akt woli organu wyrażający całkowitą aprobatę dla załatwienia sprawy w sposób wskazany przez stronę w złożonym wniosku.

J. Gurba wskazywał, że w zakresie form milczenia można wyróżnić postępowanie jednofazowe i dwufazowe ${ }^{26}$. Trzymając się tej terminologii, można wskazać, że w przypadku milczącego zakończenia spraw mowa jest o jednofazowości postępowania, a w odniesieniu do milczącej zgody - o dwufazowości postępowania. W pierwszym przypadku organ nie prowadzi czynności procesowych w celu oceny, czy sprawę załatwić w terminie, czy może jednak doprowadzić do samozałatwienia sprawy. Administracja jest w tym przypadku bierna, wręcz pasywna. Postępowanie dwufazowe dotyczące milczącej zgody polega na prowadzeniu przez organ czynności procesowych polegających na analizie, badaniu sprawy w celu ustalenia, czy wnieść sprzeciw. Świadome niewniesienie sprzeciwu jest poprzedzone działaniem organu administracji.

W świetle uzasadnienia do projektu uchwalonej ustawy milcząca zgoda klasyfikowana powinna być jako akt administracyjny konkludentny/dorozumiany zależny od woli organu administracji, stanowiący jedną z tradycyjnych form działania administracji ${ }^{27}$. Natomiast w odniesieniu do milczącego załatwienia sprawy ustawodawca nie posługuje się już terminem aktu ani też nie wskazuje, że jest to działanie zależne od woli organu ${ }^{28}$. Do koncepcji milczącego załatwienia sprawy w takim ujęciu pasuje określenie go jako zdarzenia prawnego będącego działaniem organu administracji, który nie wydaje aktu administracyjnego. Taka niespójność w ramach jednej instytucji prawnej nie tylko budzi wątpliwości, czy ustawodawca celowo określił w uzasadnieniu projektu ustawy o zmianie ustawy - Kodeks postępowania administracyjnego

${ }^{24}$ Uzasadnienie do ustawy o zmianie ustawy - Kodeks postępowania administracyjnego..., s. 45-46.

${ }^{25}$ Ibidem, s. 46.

${ }^{26}$ W. Gurba, Zwalczanie i zapobieganie bezczynności oraz przewlekłości postępowania administracyjnego, „Państwo i Prawo” 2015, z. 11, s. 12.

${ }^{27}$ Uzasadnienie do ustawy o zmianie ustawy - Kodeks postępowania administracyjnego..., s. 47.

${ }^{28}$ Ibidem. 
oraz niektórych innych ustaw w odmienny sposób określenia klasyfikujące poszczególne postaci milczącego załatwienia sprawy, czy taka niespójność nie była jego zamierzeniem.

Przeanalizować zatem należy, czy w przypadku milczącej zgody zostaje wydany jakikolwiek akt administracyjny indywidualny i konkretny. W tym celu należy posłużyć się definicją K.M. Ziemskiego, który ustalił pełną definicję aktu administracyjnego jako czynności prawnej, która stanowi zmierzające do wywołania bezpośrednich skutków prawnych władcze, kierowane na zewnątrz administracji oświadczenie woli kompetentnego podmiotu wykonującego zadania z zakresu administracji publicznej, wyrażające rozstrzygnięcie co do konsekwencji prawnych, a więc konsekwencji normy bądź norm generalnych, dla zindywidualizowanego (od strony podmiotowej oraz przedmiotowej) stanu faktycznego, dotyczące indywidualnie wskazanych podmiotów, wyznaczając im zachowania w konkretnie określonych sytuacjach, w sposób bezpośredni wywołując zamierzony skutek prawny i w ten sposób załatwiając sprawę ${ }^{29}$.

W takim ujęciu trudno zawrzeć milczącą zgodę, która nie wyraża rozstrzygnięcia co do konsekwencji prawnych, a więc konsekwencji normy bądź norm generalnych, dla zindywidualizowanego (od strony podmiotowej oraz przedmiotowej) stanu faktycznego, bowiem te konsekwencje prawne wynikają z mocy samej ustawy i wręcz żaden akt indywidualny i konkretny nie może zostać wydany. Artykuł 122c k.p.a. stanowi, że milczące załatwienie sprawy, w którym mieści się pojęcie milczącej zgody, następuje w dniu następującym po dniu, w którym upływa termin przewidziany do wydania decyzji lub postanowienia kończącego postępowanie w sprawie albo wniesienia sprzeciwu.

Przyjąć zatem należy, że ramowa regulacja kodeksowa milczącego załatwienia sprawy przyjmuje koncepcję milczenia jako zdarzenia prawnego będącego zależnym od woli organu działaniem administracji publicznej, które wywołuje skutki prawne na mocy samej ustawy stanowiącej normę materialnoprawną. Milczenie organu administracji publicznej, obok decyzji rozstrzygającej sprawę indywidualną co do istoty, a także decyzji w przedmiocie umorzenia bezprzedmiotowego postępowania, stanowi trzeci sposób załatwienia sprawy niebędący aktem, stanowiący wyjątek od zasady, że to decyzja albo postanowienie stanowi formę prawną załatwienia sprawy (aktywne działanie administracji).

${ }^{29}$ K.M. Ziemski, Koncepcja milczenia jako prawnej formy działania administracji publicznej, w: System Prawa Administracyjnego, t. 5: Prawne formy działania administracji, pod red. A. Błasia, J. Bocia, M. Stahl, K.M. Ziemskiego, Warszawa 2013, s. 390-394. 
Takie ujęcie nie powoduje także zagrożenia odhumanizowania działania administracji, administracja ma być bowiem świadoma swojego wyboru działania polegającego na zaniechaniu w postaci zakończenia sprawy bądź niewyrażenia sprzeciwu. Niewątpliwie, prawidłowe zdefiniowanie instytucji milczącego załatwienia sprawy w Kodeksie postępowania administracyjnego za pomocą definicji równościowej klasycznej - wyeliminowałoby wiele dywagacji na temat klasyfikacji milczenia administracji publicznej. Tymczasem jednak charakteru takiej definicji nie ma regulacja $z$ art. 122 a $\$ 2$ k.p.a. Ustawodawca nie wyjaśnia charakteru prawnego milczenia organu administracji publicznej. O ile nie budzi w zasadzie obecnie wątpliwości, że milczenie stanowi odrębną kategorię względem bezczynności organu, o tyle samo milczenie, pomimo wprowadzenia regulacji ramowej tej instytucji, nadal pozostaje rozbieżnie ujmowane $\mathrm{w}$ doktrynie.

Takie rozbieżności nie pozostaną bez wpływu na ocenę i sposób stosowania w praktyce kodeksowej instytucji milczącego załatwienia sprawy.

\section{Praktyka stosowania milczącego załatwienia sprawy - rozważania prawnomaterialne}

Zgodnie z założeniem ustawodawcy wprowadzana w przepisach rozdziału 8a działu II k.p.a. instytucja milczącego załatwienia sprawy umożliwić miała przyspieszenie i uproszczenie postępowań administracyjnych, a także usprawnienie i zmniejszenie kosztów funkcjonowania administracji publicznej ${ }^{30}$. Ten cel może zostać w pełni zrealizowany wówczas, gdy ustawodawca ustanowi przepisy szczególne prawa materialnego, które będą przewidywały milczące załatwienie sprawy w tych wszystkich sprawach, dla których taki rodzaj zakończenia sprawy nie naruszy praw strony ani osób trzecich. Takie zadanie postawił przed sobą ustawodawca w szczególności w sprawach, w których stopień ich skomplikowania nie jest wysoki, a ryzyko naruszenia interesu publicznego czy pewności obrotu w wyniku ewentualnego, niezamierzonego przez organ, milczącego załatwienia sprawy jest niewielkie. Zwrócić należy uwagę, że w ten sposób powinny być załatwiane sprawy, w których nie występują strony o spornych interesach. Nadto ustawodawca

${ }^{30}$ Uzasadnienie do ustawy o zmianie ustawy - Kodeks postępowania administracyjnego..., s. 45 . 
zadecydował, że w postępowaniu uproszczonym co do zasady stosowane będą przepisy o milczącym załatwieniu sprawy, o ile przepisy szczególne nie będą wyłączały takiej możliwości.

Należy zaakcentować, że stosowanie instytucji milczącego załatwienia sprawy jest możliwe tylko i wyłącznie w postępowaniu przed organem I instancji. Zgodnie z założeniami do projektu nowelizacji $\mathrm{w}$ postępowaniu odwoławczym oraz w sprawach wszczętych w trybach nadzwyczajnych, tj. w postępowaniu o wznowienie postępowania, stwierdzenie nieważności decyzji czy uchylenie bądź zmianę decyzji ostatecznej, instytucji milczącego załatwienia sprawy stosować nie można ${ }^{31}$. Słusznie ustawodawca nie dopuścił możliwości sięgnięcia do tej instytucji w postępowaniu odwoławczym, co wynika z konstrukcji tej instytucji i znajduje odzwierciedlenie w art. 138 § 1 i 2 k.p.a. w zw. $z$ art. $122 a \S 1$ k.p.a.).

Ramowy charakter regulacji milczącego załatwienia sprawy w k.p.a. powoduje, że należy przeanalizować przepisy prawa materialnego stanowiące o milczeniu organów administracji publicznej wywołującym skutki prawne. Jak stanowi art. 1 pkt 1 k.p.a., w przepisach materialnego prawa administracyjnego pojawiła się nowa, alternatywna wobec decyzji administracyjnej, prawna forma działania administracji, tj. milczenie organu, umożliwiająca rozstrzygnięcie (załatwienie) sprawy indywidualnej.

Po pierwsze, w gestii ustawodawcy pozostaje uregulowanie możliwości załatwienia sprawy przez administrację publiczną milcząco, tak by ją odciążyć i przyspieszyć postępowania administracyjne. Analiza przepisów ustaw materialnych pokazuje, w ilu realnie przypadkach stosowanie milczącego załatwienia sprawy jest dopuszczalne. Po drugie, to na ustawodawcy ciąży obowiązek rozsądnego wyważenia, do jakiej kategorii spraw może mieć zastosowanie milczenie organów administracji, tak aby z jednej strony przeciwdziałać bezczynności, z drugiej zaś nie doprowadzać do automatycznego załatwiania pozytywnie w tym trybie spraw, które mają duże znaczenie dla interesu publicznego, bezpieczeństwa obrotu prawnego, a wymagających większego zaangażowania, również czasowego.

Historycznie spoglądając na instytucję milczenia administracyjnego, wskazać należy, że już w okresie Królestwa Polskiego, a następnie po odzyskaniu przez Polskę niepodległości prawodawca nadawał znaczenie prawne milczeniu organów administracji. Można wskazać pewne

${ }^{31}$ Ibidem, s. 46. 
przykłady milczącego załatwienia sprawy, uregulowane chociażby w dekrecie z dnia 4 lutego 1919 r. o samorządzie miejskim w b. Królestwie Kongresowym $^{32}$. W art. 39 dekret stanowił o instytucji milczenia w sferze wewnętrznej, w stosunku do aktów generalnych organów administracji, tj. wskazywał, że uchwały rady miejskiej, wymagające zgody władzy nadzorczej, wprowadza się w wykonanie, o ile władza nadzorcza w ciągu dwóch tygodni od chwili otrzymania tych uchwał nie zawiesi ich lub nie zakaże ich wykonania.

Kolejny przykład milczenia uregulowany w dekrecie z dnia 7 lutego 1919 r. o zakładach drukarskich ${ }^{33}$, dotyczący podejmowania działalności gospodarczej, w art. 4 stanowił, że o ile w ciągu dwóch tygodni od zawiadomienia o zamiarze założenia zakładu nie nastąpiła odmowna odpowiedź władzy administracyjnej, to jest to zrównane $z$ wydaniem aktu pozytywnego. Natomiast w dekrecie z dnia 7 lutego $1919 \mathrm{r}$. w przedmiocie tymczasowych przepisów prasowych ${ }^{34}, \mathrm{w}$ art. 17 upoważniono władzę administracyjną do zabronienia wydawania czasopisma z przyczyn $w$ ustawie wymienionych $w$ ciągu siedmiu dni od złożenia deklaracji o zamiarze wydawania czasopisma. $W$ razie niewydania zakazu w oznaczonym terminie czasopismo mogło wychodzić. Był to przykład aktywnej milczącej zgody, poprzez niewydanie zakazu.

Z kolei Ustawa z dnia 18 lipca 1924 r. w sprawie zmian przepisów budowlanych dla $\mathrm{wsi}^{35} \mathrm{w}$ art. 2 uzależniała wznoszenie nowych budowli parterowych od pozwolenia wójta. O ile w ciągu trzech tygodni od chwili zgłoszenia prośby nie nastąpiła odpowiedź, pozwolenie należało uważać za udzielone na warunkach wyszczególnionych w prośbie. Jest to przykład milczenia pasywnego.

Już w roku 1926 B. Wasiutyński wskazywał dwie formy milczenia organów administracyjnych, podkreślając: „[n]asze ustawy, jeżeli chcą normą prawną zastąpić ewentualny brak przejawu woli ze strony administracji, posługują się formą pozytywną w interpretacji milczenia. A to $\mathrm{w}$ dwojakiej postaci. Albo nakazują uważać milczenie za zgodę na uchwałę, zawiadomienie, podanie, albo też milczenie władzy jest uważane za niekorzystanie z prawa zakazu, czyli w sposób pośredni wynika pozytywna zgoda na załatwienie sprawy"36. Wskazane przez

\footnotetext{
32 Dz.P. 1919 Nr 13, poz. 140.

${ }^{33}$ Dz.P. 1919 Nr 14, poz. 146.

${ }^{34}$ Dz.P. 1919 Nr 14, poz. 186.

${ }^{35}$ Dz.U. 1924 Nr 73, poz. 715.

${ }^{36}$ B. Wasiutyński, Milczenie władz administracyjnych, "Ruch” 1926, nr 4, s. CCIV.
} 
B. Wasiutyńskiego dwie formy milczenia to milczenie czynne/aktywne oraz milczenie bierne/pasywne. Milczenie przez określony czas stanowiące zgodę na dokonane działanie wnioskodawcy stanowi przykład milczenia pasywnego, natomiast niekorzystanie z prawa zakazu, odmowy, złożenia sprzeciwu stanowi aktywną milczącą zgodę.

Powyższe prowadzi do wniosku, że już w dwudziestoleciu międzywojennym prawodawca widział potrzebę regulacji milczenia administracji jako gwarancji dla administrowanych, że administracja nie będzie przez dłuższy czas hamowała ich działalności. Regulowanie przepisami prawnymi milczenia organu administracji miało na celu usprawnienie administrowania. Zastanawiano się wówczas, czy można przypisać milczeniu przejaw woli, jeśli przepis materialnoprawny o tym wyraźnie nie stanowi. B. Wasiutyński wskazywał kategorycznie, że o ile milczenie $\mathrm{w}$ prawie prywatnym może zostać uregulowane w sposób ogólny i wywoływać skutki prawne, o tyle administrowanie to proces stały i nieprzerwany. Nie można domniemywać bez stosownych podstaw prawnych, że bierności administracji przypisywać należy pozytywne skutki prawne. Niedziałanie władzy, bez wyraźnej ku temu podstawy prawnej, nie może być tłumaczone, usprawiedliwiane i uważane za formę działania ${ }^{37}$. W tych przypadkach powstrzymanie się od decyzji nie byłoby zgodne z prawem. Koncepcja ta przyświeca ustawodawcy polskiemu do dnia dzisiejszego. Dlatego też niezmiernie ważna jest analiza regulacji norm prawa materialnego zezwalających na przypisanie skutków prawnych milczeniu organów administracji publicznej.

Przez lata instytucja milczenia w polskim prawie administracyjnym była konstrukcją uregulowaną w ustawach prawa materialnego, jednakże miała charakter materialny i procesowy. Ustawy prawa materialnego zawierają bowiem także przepisy o charakterze procesowym. Zjawisko milczenia administracji po II wojnie światowej nie było zbyt powszechne i funkcjonowało jako wyjątek od zasady ${ }^{38}$. Co ciekawe, prawo materialne przewidywało także fikcję negatywnej decyzji organu na skutek milczenia. Artykuł 12 ust. 1 Ustawy z dnia 31 lipca 1981 r. o kontroli

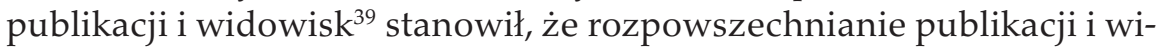
dowisk wymagało zgody właściwego organu, któremu należało zgłosić je do kontroli. Organ kontroli wydawał w tym przedmiocie decyzję

\footnotetext{
${ }^{37}$ Ibidem, s. CCVI.

${ }^{38}$ A. Kubiak, op. cit., s. 35.

${ }^{39}$ Dz.U. 1981 Nr 20, poz. 99.
} 
o zgodzie na rozpowszechnianie bądź o zakazie rozpowszechniania publikacji lub widowiska, w całości lub w części, którą miał obowiązek doręczyć lub ogłosić stronie $\mathrm{w}$ terminach określonych $\mathrm{w}$ art. 13 tego aktu. Jeżeli w tym czasie taka decyzja nie została stronie doręczona, przyjmowano fikcję decyzji negatywnej, przewidując prawo jej zaskarżenia w drodze odwołania.

Regulacje prawne milczenia organów administracji publicznej stopniowo się rozpowszechniały. Przed nowelizacją k.p.a. wprowadzającą regulację instytucji milczącego załatwienia sprawy w prawie materialnym odnaleźć można było liczne przykłady zarówno aktywnego, jak i pasywnego milczenia administracji publicznej. Instytucję milczenia zawarto przede wszystkim w ustawach regulujących różnorodne formy działalności gospodarczej podmiotów administrowanych, tj. w art. 11 ust. 9 Ustawy z dnia 2 lipca 2004 r. o swobodzie działalności gospodarczej $^{40}$ (która utraciła moc prawną), w art. 48 Ustawy z dnia 16 lipca 2004 r. - Prawo telekomunikacyjne ${ }^{41}$, w art. 9 ust. 1 i 2 Ustawy z dnia 25 sierpnia 2006 r. o systemie monitorowania i kontrolowania jakości paliw ${ }^{42}$.

Z kolei konstrukcję „milczącego współdziałania” organów przy wydawaniu decyzji ustawodawca przewidział w ramach opiniowania i uzgodnień dotyczących ustalania warunków zagospodarowania przestrzennego, w prawie związanym z szeroko pojętym środowiskiem przyrodniczym. Przykładowo, w art. 12 ust. 3d Ustawy z dnia 16 kwietnia 2004 r. o ochronie przyrody ${ }^{43}$ uregulowano milczenie administracji co do uzgodnienia $z$ dyrektorem właściwego urzędu morskiego uznania, zmiany granic, zmiany celu ochrony lub likwidacji rezerwatu przyrody położonego na obszarze morskim, jeśli wpływa na realizację zadań dyrektora urzędu morskiego. Natomiast w Ustawie z dnia 27 kwietnia 2001 r. Prawo ochrony środowiska ${ }^{44}$, w art. 152 ust. 4 oraz art. 374 ust. 2 zawarto dwie instytucje milczenia. Pierwsza dotyczy zgłoszenia instalacji, z której emisja nie wymaga pozwolenia, a mogącej negatywnie oddziaływać na środowisko - wówczas do rozpoczęcia eksploatacji instalacji nowo zbudowanej lub zmienionej w sposób istotny można przystąpić, jeżeli organ właściwy do przyjęcia zgłoszenia w terminie

\footnotetext{
${ }^{40}$ Tekst jedn. Dz.U. 2017, poz. 2168.

${ }^{41}$ Tekst jedn. Dz.U. 2017, poz. 1907.

42 Tekst jedn. Dz.U. 2018, poz. 427.

${ }^{43}$ Tekst jedn. Dz.U. 2018, poz. 142.

${ }^{44}$ Tekst jedn. Dz.U. 2018, poz. 799.
} 
30 dni od dnia doręczenia zgłoszenia nie wniesie sprzeciwu w drodze decyzji. Jest to aktywne milczenie organu administracji publicznej. Druga regulacja dotyczy milczącego współdziałania przy wydaniu decyzji dotyczących: (1) ruchu zakładu górniczego - wymagają uzgodnienia z dyrektorem właściwego okręgowego albo specjalistycznego urzędu górniczego; (2) morskiego pasa ochronnego - wymagają uzgodnienia z właściwym dyrektorem urzędu morskiego. Niezajęcie stanowiska w terminie 14 dni przez organ właściwy do uzgodnienia oznacza brak uwag i zastrzeżeń.

Regulację milczenia pasywnego zawiera natomiast regulacja prawna z art. 38 ust. 3 Ustawy z dnia 21 marca 1985 r. o drogach publicznych ${ }^{45}$. Przepis ten stanowi, że przebudowa lub remont obiektów budowlanych lub urządzeń w pasie drogowym wymaga zgody zarządcy drogi, która to powinna nastąpić w terminie 14 dni od dnia wystąpienia $\mathrm{z}$ wnioskiem o taką zgodę, a w przypadku niezajęcia stanowiska w tym terminie uznaje się to za wyrażenie zgody.

Kolejna grupa przepisów dotyczy realizacji inwestycji gospodarczych i budowlanych. W art. 85a ust. 3 Ustawy z dnia 9 czerwca 2011 r. - Prawo geologiczne i górnicze ${ }^{46}$ ustawodawca stanowi aktywne milczenie polegające na braku wyrażenia przez ministra właściwego do spraw środowiska sprzeciwu na zgłoszenie projektu prac geologicznych.

Dalszą grupą przepisów zawierających podobne rozwiązania są przepisy niektórych ustaw korporacyjnych. Zgodnie z art. 69 ust. 1 zd. 1 Ustawy z dnia 26 maja 1982 r. Prawo o adwokaturze ${ }^{47}$ oraz z art. 311 ust. 1 zd. 1 Ustawy z dnia 6 lipca 1982 r. o radcach prawnych ${ }^{48}$ (o analogicznej treści) okręgowa rada adwokacka (rada okręgowej izby radców prawnych) przesyła wraz z aktami osobowymi do ministra sprawiedliwości w terminie 30 dni każdą uchwałę o wpisie na listę adwokatów (radców prawnych) oraz każdą uchwałę o wpisie na listę aplikantów adwokackich (radcowskich). W świetle postanowień art. 69a ust. 1 zd. 1 Prawa o adwokaturze i art. 312 ust. 1 zd. 1 ustawy o radcach prawnych wpis na listę adwokatów (radców prawnych) lub aplikantów adwokackich (radcowskich) uważa się za dokonany, jeżeli minister sprawiedliwości nie podpisze sprzeciwu od wpisu w terminie $30 \mathrm{dni}$ od dnia doręczenia uchwały wraz z aktami osobowymi kandydata.

\footnotetext{
45 Tekst jedn. Dz.U. 2017, poz. 2222.

46 Tekst jedn. Dz.U. 2017, poz. 2126.

47 Tekst jedn. Dz.U. 2017, poz. 2368.

48 Tekst jedn. Dz.U. 2017, poz. 1870.
} 
Konstrukcję milczenia stosuje ustawodawca w art. 14o Ustawy z dnia 29 sierpnia 1997 r. - Ordynacja podatkowa ${ }^{49}$, wprowadzającym instytucję tzw. milczącej interpretacji przepisów prawa podatkowego. Zgodnie z tym przepisem w przypadku niewydania przez właściwy organ interpretacji indywidualnej przepisów prawa podatkowego w terminie 3 miesięcy od dnia otrzymania wniosku uznaje się, że w dniu następującym po dniu, w którym upłynął termin wydania interpretacji, została wydana interpretacja stwierdzająca prawidłowość stanowiska wnioskodawcy w pełnym zakresie.

Regulacją stanowiącą przykład milczenia organu obowiązującą już przed nowelizacją k.p.a. był art. 6 ust. 2-4 Ustawy z dnia 7 listopada 2008 r. o europejskim ugrupowaniu współpracy terytorialnej ${ }^{50}$ stanowiący, że na przystąpienie do ugrupowania jednostki samorządu terytorialnego, podmiotu prawa publicznego, przedsiębiorstwa publicznego albo przedsiębiorstwa zgodę wyraża, w drodze decyzji, minister właściwy do spraw zagranicznych w uzgodnieniu z ministrem właściwym do spraw wewnętrznych, ministrem właściwym do spraw finansów publicznych oraz ministrem właściwym do spraw rozwoju regionalnego. Organ, do którego minister właściwy do spraw zagranicznych wystąił o uzgodnienie decyzji, zajmuje stanowisko w terminie 21 dni od dnia otrzymania tego wystąpienia. Niezajęcie stanowiska w terminie uznaje się za uzgodnienie decyzji. Minister właściwy do spraw zagranicznych może wystąpić do innego ministra o wyrażenie opinii w sprawie zgody na przystąpienie do ugrupowania lub zatwierdzenia jego konwencji, jeżeli jest to uzasadnione charakterem działań ugrupowania. Niezajęcie stanowiska w terminie 14 dni od dnia otrzymania wystąpienia o wyrażenie opinii uznaje się za wyrażenie opinii pozytywnej, co stanowi przykład milczącego współdziałania.

Najwięcej kontrowersji wzbudzają jednak przepisy milczenia na gruncie prawa budowlanego. W Ustawie z dnia 7 lipca 1994 r. - Prawo budowlane ${ }^{51}$ regulacja milczenia została znowelizowana Ustawą z dnia 16 grudnia 2016 r. o zmianie niektórych ustaw w celu poprawy otoczenia prawnego przedsiębiorców ${ }^{52}$. Ustawodawca zadecydował o skróceniu terminu na zastosowanie milczącej zgody, która miała na celu umożliwienie rozpoczęcia budowy w terminie jeszcze krótszym,

\footnotetext{
${ }^{49}$ Tekst jedn. Dz.U. 2018, poz. 800.

${ }^{50}$ Dz.U. Nr 218, poz. 1390.

${ }^{51}$ Tekst jedn. Dz.U. 2017, poz. 1332.

${ }^{52}$ Dz.U. poz. 2255.
} 
tj. przed upływem 21 dni, licząc od daty dokonania zgłoszenia, a nie po 30 dniach, a nadto zapewnił możliwość uzyskania zaświadczenia o braku podstaw do wniesienia sprzeciwu. Inwestor, dysponując takim zaświadczeniem, może legalnie rozpocząć budowę lub roboty budowlane, nie czekając na upływ 21-dniowego terminu. Milczenie organu zawarte jest $\mathrm{w}$ art. 30 ust. 5 i 5aa, art. 39 ust. 4, art. 54, art. 56 ust. 2, art. 67 ust. 4 oraz art. 71 ust. 4 Prawa budowlanego. Jak wynika z pierwszego spośród wymienionych przepisów, przed terminem zamierzonego rozpoczęcia robót budowlanych należy dokonać zgłoszenia budowy właściwemu organowi. Do wykonywania robót budowlanych można przystąpić, jeżeli w terminie 21 dni od dnia doręczenia zgłoszenia właściwy organ, w drodze decyzji, nie wniesie sprzeciwu. Natomiast art. 30 ust. 5aa stanowi, że organ administracji architektoniczno-budowlanej może z urzędu, przed upływem terminu 21 dni od dnia doręczenia zgłoszenia, wydać zaświadczenie o braku podstaw do wniesienia sprzeciwu. Wydanie zaświadczenia wyłącza możliwość wniesienia sprzeciwu oraz uprawnia inwestora do rozpoczęcia robót budowlanych. Regulacja ta ma uprościć i przyspieszyć postępowania budowlane.

Takie uregulowanie milczenia miało na celu uproszczenie procedury i przyspieszenie możliwości rozpoczęcia inwestycji budowlanej. Przyspieszenie powoduje, że osoba, której prawa podmiotowe lub interesy mogą być naruszone przez objęte zgłoszeniem roboty budowlane, czyli osoba spełniająca warunki określone w art. 28 k.p.a., nie może uczestniczyć w postępowaniu wszczętym wskutek wniesienia zgłoszenia budowy, nie jest ona stroną tego postępowania. Należy zauważyć, że uregulowanie milczenia w k.p.a. wyłącza stosowanie przepisów ogólnych postępowania, a organ, do którego wpłynęło zgłoszenie, podejmuje tylko czynności przewidziane w przepisach prawa budowlanego - oczywiście, jest to przykład milczenia aktywnego.

Powstaje wobec tego pytanie, czy interesy strony, np. sąsiada, zainteresowanej innym rozstrzygnięciem sprawy niż wnioskodawca, tj. interesy strony zainteresowanej wydaniem sprzeciwu przez organ administracji, są wystarczająco zabezpieczone w przypadku bezczynności organu albo potwierdzenia przez organ braku sprzeciwu. $Z$ pewnością strona taka powinna wykazać aktywność na etapie postępowania przed organem I instancji i dostarczyć argumentów przemawiających za wyrażeniem sprzeciwu. Może ona jednak nie dowiedzieć się w odpowiednim czasie o biegu terminu do milczącego załatwienia sprawy. $\mathrm{W}$ takim przypadku, po upływie terminu, sprawa zostanie rozstrzygnięta 
zgodnie z treścią wniosku wnioskodawcy, ale na niekorzyść strony zainteresowanej innym rozstrzygnięciem.

Zgodnie z art. 54 ustawy Prawo budowlane aktywne milczenie organu polega na niewniesieniu sprzeciwu w drodze decyzji w terminie 14 dni od dnia doręczenia zawiadomienia o zakończeniu budowy obiektu budowlanego, na którego wzniesienie jest wymagane pozwolenie na budowę. Brak sprzeciwu powoduje, że wnioskodawca może przystąpić do użytkowania obiektu. Przepisy prawa nie określają expressis verbis przesłanek wniesienia sprzeciwu przez organ. W orzecznictwie jednakże wskazuje się, że podstawą wniesienia sprzeciwu może być istotne odstapienie przez inwestora od projektu budowlanego lub innych warunków pozwolenia na budowę $e^{53}$, nieuzupełnienie zawiadomienia o zakończeniu budowy pomimo wezwania przez organ ${ }^{54}$, niewykonanie wszystkich robót budowlanych ${ }^{55}$. Wśród tych przesłanek orzecznictwo nie wyróżnia interesu podmiotu znajdującego się w obszarze oddziaływania obiektu.

Jak z kolei stanowi art. 71 ust. 4 ustawy Prawo budowlane, przed dokonaniem zmiany sposobu użytkowania obiektu budowlanego lub jego części należy dokonać zgłoszenia. Zmiana sposobu użytkowania może nastąpić, jeżeli w terminie $30 \mathrm{dni}$ od dnia doręczenia zgłoszenia właściwy organ nie wniesie sprzeciwu w drodze decyzji i nie później niż po upływie 2 lat od doręczenia zgłoszenia. Jest to kolejny przykład milczenia aktywnego. Przy dokonywaniu zmiany sposobu użytkowania obiektu lub jego części w każdym przypadku organ, działając w interesie publicznym, powinien przeprowadzić szczegółową ocenę nie tylko tego, czy zamierzony nowy sposób użytkowania obiektu lub jego części nie będzie kolidował z interesem użytkowników tego obiektu budowlanego, lecz także przede wszystkim tego, czy nie dojdzie do naruszenia uzasadnionych interesów osób trzecich, gdyż w postępowaniu tym, tak jak $\mathrm{w}$ postępowaniu, o którym mowa $\mathrm{w}$ art. 30 , poza podmiotem zgłaszającym nie występują jakiekolwiek inne strony, choć sprawa może dotyczyć ich interesu prawnego. Jest bowiem oczywiste, że zmiana sposobu użytkowania obiektu lub jego części może spowodować niekorzystne dla otoczenia skutki, w szczególności w sferze warunków zdrowotnych,

${ }^{53}$ Wyrok Naczelnego Sądu Administracyjnego (NSA) z 21 IX 2007 r., sygn. II OSK 1535/06, LEX nr 425357; wyrok Wojewódzkiego Sądu Administracyjnego w Gdańsku z 20 V 2009 r., sygn. II SA/Gd 104/09, LEX nr 547305.

${ }^{54}$ Wyrok NSA z 31 I 2007 r., sygn. II OSK 267/06, LEX nr 315985.

${ }^{55}$ Wyrok NSA z 27 III 2007 r., sygn. II OSK 520/06, LEX nr 503755. 
higieniczno-sanitarnych dla sąsiednich nieruchomości. Stąd milczenie administracji powinno być poprzedzone szerokimi ustaleniami organu, zwłaszcza biorąc pod uwagę brak możliwości odwoływania się od takiego pozytywnego rozstrzygnięcia przez osoby trzecie.

Nowymi regulacjami, które weszły w życie już po uchwaleniu nowelizacji k.p.a. wprowadzającej instytucję milczącego załatwienia sprawy, są przepisy: art. 53b ust. 3 Ustawy z dnia 23 stycznia 2009 r. o Krajowej Szkole Sądownictwa i Prokuratury ${ }^{56}$, dotyczący powoływania nauczycieli, oraz art. 9o ust. 5 Ustawy z dnia 28 marca 2003 r. o transporcie kolejowym ${ }^{57}$, który stanowi o uzgodnieniu projektu decyzji o ustaleniu lokalizacji inwestycji linii kolejowej w drodze decyzji z Dyrektorem regionalnego zarządu gospodarki wodnej Państwowego Gospodarstwa Wodnego Wody Polskie, w terminie 14 dni od dnia doręczenia projektu decyzji o ustaleniu lokalizacji linii kolejowej. W przypadku niezajęcia stanowiska we wskazanym terminie uzgodnienie uznaje się za dokonane.

Regulacja zawarta w art. 423 ust. 2 Ustawy z dnia 20 lipca 2017 r. Prawo wodne ${ }^{58}$ stanowi przykład milczenia aktywnego. Przepis ten stanowi, że do wykonywania czynności, robót lub urządzeń wodnych podlegających obowiązkowi zgłoszenia wodnoprawnego można przystąpić, jeżeli w terminie 30 dni od dnia doręczenia zgłoszenia organ właściwy w sprawach zgłoszeń wodnoprawnych nie wniesie, w drodze decyzji, sprzeciwu i nie później niż po upływie 3 lat od określonego w zgłoszeniu terminu ich rozpoczęcia. Dokonanie zgłoszenia wodnoprawnego nie zwalnia z obowiązku uzyskania uzgodnień i decyzji wymaganych na podstawie przepisów odrębnych.

Całkowicie nową regulacją jest art. 43 ust. 9 Ustawy z dnia 25 maja 2017 r. o restytucji narodowych dóbr kultury ${ }^{59}$ stanowiący, że pozwolenie na stały wywóz zabytku za granicę oraz na stały wywóz dobra kultury za granicę wydaje się po uzyskaniu opinii ministra właściwego do spraw zagranicznych. Opinie minister wydaje w terminie miesiąca od dnia wystąpienia o wydanie opinii. Niezajęcie stanowiska w terminie uznaje się za wyrażenie opinii pozytywnej.

${ }^{56}$ Tekst jedn. Dz.U. 2018, poz. 624.

${ }^{57}$ Tekst jedn. Dz.U. 2017, poz. 2117. Regulacja art. 9 o ust. 5 obowiązuje od 1 I 2018 r., a dodana została art. 498 pkt 1 lit. c Ustawy z dnia 20 VII 2017 r. (Dz.U. poz. 1566), zmieniającej przywołaną ustawę z dniem 1 I 2018 r.

${ }^{58}$ Dz.U. poz. 1566.

${ }^{59}$ Dz.U. poz. 1086. 
Dotychczasowe przepisy szczególne rangi ustawowej, które obowiązywały przed wejściem w życie rozdziału 8A k.p.a., mają zastosowanie według reguły lex posterior generali non derogat legi priori specialis. Natomiast nowe przepisy materialne ustaw szczegółowych mają i będą miały zastosowanie według reguły lex specialis derogat legi generali ${ }^{60}$.

Ustawodawca podjął zatem trud uchwalenia nowych przepisów stanowiących milczenie organów administracji publicznej dla wypełnienia celów zakładanych w ustawie nowelizacyjnej k.p.a. Nowelizacja jednak nie wpłynęła w żaden sposób na zwiększenie liczby spraw załatwianych milcząco na gruncie ustaw materialnych obowiązujących jeszcze przed wejściem w życie nowelizacji k.p.a. ${ }^{61} \mathrm{Na}$ gruncie prawa budowlanego formułowanych jest wiele zarzutów pod adresem milczącego załatwienia sprawy. Organy administracji architektoniczno-budowlanej pomimo przyznania im kompetencji do wydawania zaświadczeń o braku podstaw do wniesienia sprzeciwu nie wydają takich zaświadczeń z urzędu, gdyż termin na milczące przyjęcie zgłoszenia wobec ogromnej liczby wpływających tego rodzaju spraw i tak jest zbyt krótki na rzetelne sprawdzenie załączonej dokumentacji ${ }^{62}$. Zmiany w k.p.a. miały ułatwić i przyspieszyć rozpatrywanie spraw w organach administracji publicznej, lecz efekt ten, niestety, nie został osiągnięty na gruncie prawa budowlanego. Strony postępowań mają problemy z rozróżnieniem procedur zgłoszeń, tj. zgłoszeń zwykłych i zgłoszeń z obligatoryjnym projektem. $Z$ tego powodu, pomimo możliwości skorzystania z uproszczonych form zgody budowlanej (zgłoszenia z projektem), w dalszym ciągu preferują postępowania zakończone wydaniem decyzji administracyjnej. Jak wskazuje A. Gronkiewicz, jednostki często unikają korzystania z trybu milczącego załatwienia sprawy ze względu na poczucie niepewności co do milczenia administracji, dlatego też autorka niniejszego opracowania zaproponowała przeprowadzenie stosownej kampanii informacyjnej, wskazującej na to, że milczenie

\footnotetext{
${ }^{60}$ A. Wiktorowska, Milczace załatwienie sprawy, w: Postępowanie administracyjne - ogólne, podatkowe, egzekucyjne i przed sądem administracyjnym, pod red. M. Wierzbowskiego, M. Szubiakowskiego, A. Wiktorowskiej, Warszawa 2017, s. 193.

${ }^{61}$ Przykładowo, liczba załatwionych milcząco spraw w okresie od 1 VI 2017 r. do 31 III 2018 r. na podstawie art. 30 ust. 5 Prawa budowlanego w porównaniu z okresem od 1 VI 2016 r. do 31 III 2017 r. nie zwiększyła się (zob. statystyki spraw załatwianych milcząco przez Prezydenta Miasta Poznaniu uzyskane w trybie dostępu do informacji publicznej w dniu 24 IV 2018 r.).

${ }^{62}$ D. Kafar, Milczące załatwienie zgłoszenia budowlanego po nowelizacji k.p.a., "Wspólnota” 20 IX 2017, s. 3.
} 
jest równoznaczne z załatwieniem sprawy ${ }^{63}$. Niewątpliwie, takie akcje stanowiące działania organizatorskie administracji byłyby przydatnym narzędziem zwiększenia efektywności instytucji milczenia administracji. Ukazuje to, że wprowadzenie do k.p.a. regulacji milczącego załatwienia sprawy nie rozwiązuje raz na zawsze wszelkich problemów związanych z tą instytucją prawną.

W istotny sposób na zwiększenie liczby spraw załatwianych milcząco wpływać ma regulacja możliwości stosowania milczenia w postępowaniu uproszczonym. Postępowanie uproszczone charakteryzuje się szybkością działania organu, ograniczonym formalizmem czynności, nieobszerną regulacją prawną oraz szeroką dostępnością postępowania dla różnych podmiotów. Organ administracji publicznej może załatwić sprawę w postępowaniu uproszczonym wyłącznie wtedy, gdy wynika to z przepisów szczególnych, a zatem rozszerza się katalog spraw, w których można zastosować milczenie organu.

W postępowaniu uproszczonym co do zasady stosowane są przepisy o milczącym załatwieniu sprawy, o ile przepisy szczególne nie wyłączały takiej możliwości. Oznacza to, że w postępowaniu uproszczonym stosowanie przepisów o milczącym załatwieniu sprawy można traktować jako zasadę, o ile nie zostanie ona ograniczona przepisami szczególnymi zawartymi poza Kodeksem postępowania administracyjnego.

$\mathrm{Z}$ całą mocą podkreślić jednak należy, że art. 163b k.p.a. nie stanowi wyłącznej podstawy stosowania w danym postępowaniu trybu uproszczonego. Konieczne jest dopuszczenie przez przepis szczególny załatwiania spraw danego rodzaju w tym trybie. Przepisem szczególnym $\mathrm{w}$ rozumieniu komentowanego przepisu jest przepis kodeksu lub przepis innej ustawy, wskazujący na możność załatwiania spraw danego rodzaju w postępowaniu uproszczonym. Taka regulacja stawia przed ustawodawcą kolejne wyzwanie prawidłowego doboru spraw procedowanych w trybie uproszczonym.

Przedstawiona powyżej analiza polskich przykładów milczenia organu administracji publicznej ukazuje, że ramowa regulacja kodeksowa, niepołączona z działaniami ustawodawcy na gruncie prawa materialnego, nie przyczyni się do właściwej praktyki stosowania tej formy działania przez organy administracji publicznej, a zwłaszcza realizacji jej celu głównego, jakim było przyspieszenie postępowań administracyjnych.

${ }^{63}$ A. Gronkiewicz, op. cit., s. 240. 


\section{Weryfikacja milczenia jako prawnej formy działania administracji}

Ustawodawca przyjął, że skoro milczące załatwienie sprawy (czyli wywołanie skutku prawnego poprzez zaniechanie) jest możliwe jedynie $\mathrm{w}$ postępowaniu wszczętym na wniosek strony, nigdy z urzędy, oraz jeżeli można w całości uwzględnić żądanie strony, to gwarancje dla wnioskodawcy nie wymagają kontroli instancyjnej czy też sądowoadministracyjnej ${ }^{64}$.

Milczące załatwienie sprawy jako szczególny sposób działania administracji ma swoje odrębności. Kontrola instancyjna milczenia administracyjnego jest możliwa w przypadku spraw, które mogą być załatwiane milcząco, ale organ wydał decyzję negatywną, postanowienie bądź wniósł sprzeciw.

Natomiast na postanowienie w sprawie załatwienia sprawy milcząco przysługuje zażalenie zarówno stronie żądającej załatwienia sprawy milcząco, jak i innym stronom postępowania (podmiotom, których interesu prawnego lub obowiązku dotyczy postępowanie), a które nie żądały załatwienia sprawy milcząco.

W stosunku do milczącego załatwienia sprawy na gruncie ustaw prawa materialnego nie przysługują żadne środki prawne pozwalające na zakwestionowanie i weryfikację milczącego załatwienia sprawy w trybie odwołania i skargi do sądu administracyjnego. Przepisy k.p.a. także nie stanowią normy zapewniającej możliwość zaskarżenia na ogólnych zasadach k.p.a. ani w drodze skargi do sądu administracyjnego milczącego załatwienia sprawy. Ustawodawca bowiem nie zdecydował się na zmianę katalogu aktów, czynności i zaniechań podlegających kontroli sądów administracyjnych $\mathrm{z}$ art. $3 \S 2$ Prawa o postępowaniu przed sądami administracyjnymi ${ }^{65}$. W tym przypadku nie mamy bowiem do czynienia z decyzją ani z innym aktem lub czynnością, która mogłaby stać się przedmiotem postępowania odwoławczego albo kontroli sądu administracyjnego. Taka regulacja, w przypadku gdy milczenie załatwia sprawę, w której stroną mogłyby być podmioty, w stosunku do których milczenie wywołuje skutki prawne mające sprzeczne interesy z wnioskodawca, nie jest prawidłowa. Jedynie wyważone ustawodawstwo

${ }^{64}$ Uzasadnienie do ustawy o zmianie ustawy - Kodeks postępowania administracyjnego..., s. 47.

${ }^{65}$ Ustawa z dnia 30 VIII 2002 r. - Prawo o postępowaniu przed sądami administracyjnymi (tekst jedn. Dz.U. 2017, poz. 1369). 
w kwalifikowaniu spraw, które mogą być załatwione milcząco, będzie przeciwdziałać pozbawianiu gwarancji proceduralnych osoby trzecie o spornych interesach w stosunku do interesu wnioskodawcy.

Uregulowanie wyłącznie możliwości ponownego rozpatrzenia sprawy załatwionej milcząco $\mathrm{w}$ razie spełnienia przesłanek właściwych dla trybów nadzwyczajnych (w szczególności wznowienie postępowania i stwierdzenie nieważności decyzji) w takich sprawach nie jest wystarczające.

Przepisy regulujące tryby nadzwyczajne postępowania administracyjnego znajdują odpowiednie zastosowanie do spraw załatwionych milcząco. Zastosowanie przepisów o trybach nadzwyczajnych jest jedynie odpowiednie, o czym stanowi art. 122g k.p.a.; wynika to z konieczności przyjęcia domniemania prawnego wydania aktu administracyjnego w sprawach załatwianych milcząco. Odpowiednie zastosowanie art. 145-163 k.p.a. do milczącego zakończenia postępowania lub milczącej zgody oznacza, że część przepisów stosuje się z pewnymi modyfikacjami, a części z nich nie stosuje się w ogóle.

Sposoby weryfikacji spraw załatwianych milcząco ukazuja, że ten sposób załatwienia sprawy przesądza o odmienności postępowania administracyjnego ogólnego od postępowania skróconego unormowanego w art. od 122a do $122 \mathrm{~g}$ k.p.a., a także od postępowań uproszczonych załatwianych bez zastosowania milczenia, uregulowanych $\mathrm{w}$ art. od 163 b do 163 g k.p.a.

Przykładowo, we Francji jest możliwe złożenie skargi do sądu administracyjnego na milczenie na podstawie ustawy nr 2000-321 w sprawie praw obywateli w ich stosunkach $\mathrm{z}$ organami administracji, celem jest tu jednak przeciwstawienie się fikcji negatywnego załatwienia sprawy. Tego rodzaju milczenie jest rozumiane na gruncie prawa polskiego jako bezczynność, która może być również przedmiotem zaskarżenia do sądu administracyjnego. W prawie francuskim zasadą jest bowiem, że milczenie administracji skutkuje fikcją wydania decyzji negatywnej (odmownej), fikcja decyzji pozytywnej następuje natomiast wówczas, gdy przewidują to dekrety Conseil d'Etat, a nadto przepisy ustawowe wyłączają taki skutek, gdy sprzeciwiałyby się temu międzynarodowe zobowiązania Francji, porządek publiczny, ochrona swobód lub ochrona innych wartości konstytucyjnych. Ustawa nr 2000-321 przewiduje jednak możliwość wzruszenia decyzji pozytywnej poprzez jej cofnięcie z powodu jej nielegalności, czyli wprowadza wzruszalność w trybach nadzwyczajnych, podobnie jak obecnie uregulowano to w polskim k.p.a. 
Podobnie w Hiszpanii odwołanie może zostać wniesione wyłącznie w stosunku do milczenia wywołującego negatywny skutek, czyli odmowę uprawnienia ${ }^{66}$. Biorąc to pod uwagę, ograniczenie możliwości kontroli zarówno przez organ II instancji, jak i sąd administracyjny pozytywnego milczenia $\mathrm{w}$ prawie polskim nie stanowi odstępstw od regulacji innych państw członkowskich Unii Europejskiej.

Trafnie jednak wskazał J. Borkowski, że milczenie nie może być stosowane do szerokiej kategorii spraw, ponieważ ukazuje ono bezsilność państwa wobec zaniechań administracji, które także nie podlegają szerokiej kontroli organów oraz sądów administracyjnych ${ }^{67}$.

Do istotnych gwarancji ustawodawca zaliczył jednak możliwość sprostowania lub uzupełnienia żądania $z$ art. 122c $\S 2$ k.p.a. W sprawach załatwianych milcząco precyzyjne ustalenie treści żądania zawartego we wniosku strony ma zasadnicze znaczenie, bowiem milczenie stanowi o całościowym uwzględnieniu żądania strony. Regulacja wezwania do uzupełnienia braków podania bądź wniosku lub doprecyzowanie jego treści stanowi instrument gwarantujący pozytywne załatwienie sprawy. Sądzić należy a contrario, że jeśli strona nie uzupełniła braków wniosku albo nie doprecyzowała treści żądania, bądź też dokonała tych czynności w sposób niepełny lub wadliwy, to organ jest obowiązany do załatwienia sprawy $w$ formie odmownej decyzji administracyjnej lub postanowienia, bądź wniesienia sprzeciwu, w zależności od normy prawa materialnego. Tylko bowiem taka forma prawna załatwienia sprawy umożliwia podjęcie ochrony prawnej w postaci złożenia środka zaskarżenia od rozstrzygnięcia organu I instancji.

Milczące załatwienie sprawy ze względu na swój niezmaterializowany charakter w celu ochrony pewności prawa może zostać uzewnętrznione w dwojaki sposób. Po pierwsze, za sprawą adnotacji zamieszczonej w aktach sprawy (art. 122e k.p.a.) albo, po drugie, za pomoca zaświadczenia o milczącym załatwieniu sprawy (art. 122f k.p.a.). Adnotacja ma charakter wyłącznie informacyjny i porządkowy. Natomiast zaświadczenie ma charakter deklaratoryjny, wydawane jest $\mathrm{w}$ formie postanowienia, którym strona może się posługiwać w obrocie prawnym w celu wykazania, że sprawa została pozytywnie załatwiona. Niewątpliwie, możliwość uzyskania potwierdzenia załatwienia sprawy milcząco

${ }^{66}$ P. Dobosz, Milczenie i bezczynność..., s. 457.

${ }^{67}$ J. Borkowski, Francja, w: Postępowanie administracyjne w Europie, pod red. Z. Kmieciaka, Zakamycze 2005, s. 147 i n. 
w formie pisemnej zwiększy poczucie pewności administrowanych co do tej formy załatwienia sprawy.

Ustawodawca zdecydował zaświadczenia w sprawie milczącego załatwienia sprawy wydawać jako akty administracyjne będące władczym i jednostronnym oświadczeniem woli organu. Są to zatem deklaratoryjne akty administracyjne, które potwierdzają, a nie zmieniają stan prawny, ich waga jest jednak na tyle doniosła, że przysługuje od nich zażalenie. Takie zażalenie nie może czynić jednak zarzutów w stosunku do pozytywnego załatwienia sprawy, ale jedynie może dotyczyć odmowy wydania zaświadczenia. Wszystkie strony postępowania administracyjnego mogą skarżyć zaświadczenie o milczącym załatwieniu sprawy.

Taki wybór przez ustawodawcę formy prawnej zaświadczenia budzi wątpliwości i z całą pewnością nie służy ujednoliceniu poglądów na rozumienie prawnych form działania administracji. Artykuł $217 \S 2$ pkt 2 k.p.a. określa zaświadczenie jako urzędowe potwierdzenie określonych faktów lub stanu prawnego. Od lat wskazuje się bowiem, że należy odróżniać czynności materialno-techniczne będące czynnościami faktycznymi od aktów administracyjnych deklaratoryjnych będących czynnościami prawnymi. Zaświadczenia już z samego faktu ich charakteru poświadczania, czyli urzędowego uzewnętrznienia uprawnienia obiektywnie zaistniałego na skutek milczenia administracji, stanowić powinny czynność materialno-techniczna, mającą doniosłość czysto praktyczną i dowodową ${ }^{68}$. Trudno zgodzić się z ustawodawca, że takie działanie administracji, jakim jest wydanie zaświadczenia, stanowi akt władczy. Abstrahując jednak od powyższych sporów, należy zauważyć, że nie można postawić znaku równości między pojęciem zaświadczenia a aktem administracyjnym o charakterze deklaratoryjnym. Akt deklaratoryjny bowiem $\mathrm{w}$ istocie swej potwierdza stan faktyczny lub prawny, ale rodzi także skutki prawne. Natomiast zaświadczenie jedynie potwierdzi istnienie owych faktów, nie rodząc przy tym jednak skutków bezpośrednich. Można więc przyjąć, że w przypadku, gdy sytuacja prawna (uprawnienie lub obowiązek) powstaje z mocy samego prawa, z decyzją administracyjną (deklaratoryjną) mamy do czynienia tylko wtedy, gdy chodzi o ustalenie tej sytuacji w sposób wiążący, gdy występowanie pewnych okoliczności w konkretnym przypadku budzi wątpliwości lub

${ }^{68} \mathrm{~W}$ prawie francuskim w przypadku milczenia, które na podstawie dyrektyw stanowi o pozytywnym załatwieniu spraw, wydawane są poświadczenia kwalifikowane jako czynności materialno-techniczne, zob. Z. Kmieciak, Zarys teorii postępowania administracyjnego, Warszawa 2014, s. 256. 
gdy istnieje co do tego spór. Jeżeli natomiast fakt spełnienia przesłanek, z którymi przepis prawa wiąże określone skutki prawne, jest oczywisty i bezsporny, nie może być mowy o rozstrzyganiu czegokolwiek i nie wymaga to wydania decyzji administracyjnej, postanowienia ${ }^{69}$.

\section{Podsumowanie}

Niewątpliwie, zarówno normy prawa materialnego, jak i procesowego w zakresie regulacji milczącego załatwienia sprawy są potrzebne i niezbędne. Jeśli bowiem chodzi o prawo materialne, to stanowić powinno wyraz przemyślanej koncepcji, w jakich sprawach stosować można milczenie organów administracji, nie naruszając ani interesu publicznego, ani interesów jednostek, i to nie tylko wnioskodawcy, ale też pozostałych stron postępowania. Natomiast regulacje proceduralne mają stanowić gwarancję ochrony praw administrowanych przed zaniechaniem administracji, bezczynnością i przewlekłością w jej działaniu.

Posługiwanie się przez ustawodawcę fikcją decyzji pozytywnej ma na celu uproszczenie i odbiurokratyzowanie postępowania administracji publicznej, całkowicie eliminując ryzyko zwłoki w działaniach administracji. Posługiwanie się nią nie jest jednak wolne od wad oraz ryzyka. Niebezpieczeństwo związane z milczącym załatwieniem sprawy polega przede wszystkim na ograniczonej możliwości poznania motywów stanowiska organu, a więc i zweryfikowania poprawności pozytywnego rozstrzygnięcia przez adresata, a zwłaszcza przez osoby trzecie, jeśli ich interesu prawnego dotyczy milczenie.

Ze względu na znaczne ograniczenie możliwości kontroli milczącego załatwienia sprawy ciężar zapewnienia prawidłowego zabezpieczenia interesów podmiotów innych niż wnioskodawca należy do ustawodawcy, który stanowi przepisy szczególne i dokonuje wyboru rodzajów spraw, które będą mogły być załatwiane w sposób milczący. Wskazać należy, że rodzaje spraw, w których ma zastosowanie milczenie organu administracji publicznej, nie powinny być ograniczane wyłącznie do spraw rejestrowych czy regulacyjnych ze względu na to, że w tych sprawach nie dochodzi do nadmiernego wydłużania postępowań. Sprawami, które wymagają prawidłowo działających procedur samozałatwiania spraw, są chociażby regulacje prawa budowlanego, z tym, że samo

${ }^{69}$ K. Chorąży, Z.R. Kmiecik, Wydawanie zaświadczeń - kwestie nie rozstrzygnięte w literaturze, "Samorząd Terytorialny” 2000, nr 6, s. 4. 
wprowadzenie do k.p.a. regulacji proceduralnej milczenia organów nie spowodowało przełomu w zakresie sprawności załatwiania tych spraw. W celu poprawy efektywności stosowania milczenia administracyjnego niezbędna jest także zmiana mentalna administrowanych w odniesieniu do trybu załatwiania spraw za pomocą milczenia organu.

Nie sposób pominąć także istotnego zagrożenia związanego z szerokim stosowaniem milczenia przez organy administracji, jakim jest uśpienie administracji, wywołanie jej bierności, a dalej, jak wskazuje D. Sześciło, stopniowe ustępowanie organów administracji z pozycji gwaranta rzetelnego stosowania prawa i ochrony zarówno interesu publicznego, jak i interesu obywateli ${ }^{70}$. Zgodzić się należy z tym autorem, ponieważ cel $\mathrm{w}$ postaci szybkości załatwienia spraw nie może być nadrzędny nad zasadą prawdy obiektywnej. Takie administrowanie przeczyłoby bowiem zasadzie zaufania do organów administracji publicznej.

Ustawodawca powinien kwalifikować sprawy do rozpoznawania w trybie uproszczonym w sposób przemyślany, a także w sposób rozważny regulować kompetencje organów administracji do załatwiania spraw milcząco.

\section{SILENCE OF ADMINISTRATIVE BODIES AS AN INSTITUTION OF ADMINISTRATIVE SUBSTANTIVE AND PROCEDURAL LAW}

\section{S u m mary}

The aim of the article is to examine the institution of "Silent settlement of the matter" regulated in the Code of Administrative Procedure, as well as in the provisions of substantive law.

In a number of Polish laws, the inaction of the administration is seen as bound to have certain legal consequences. Such rules cause many doubts both at the theoretical and practical level, and raise questions about the antidote to such unwanted inactivity of administration. The general clause of positive or negative fictitious adjudication in administrative matters is present in many legal systems. However, in the Polish legal system it lacks a legal definition and the silent settlement handling of the case entails problems of its classification as part of the legal forms of administration.

${ }^{70}$ Tak też: D. Sześciło, Milczaca zgoda organu - instrument przeciwdziałania przewlekłości postępowania czy narzędzie deregulacji?, w: Kodeks postępowania administracyjnego Unii Europejskiej, pod red. J. Supernata, B. Kowalczyk, Warszawa 2017, s. 276, oraz A. Gronkiewicz, op. cit., s. 240. 
The article shows that the mere introduction of procedural regulations will not result in a breakthrough in the institution of silent positive settlement of the matter, if the legislator does not balance the types of cases to which silence can be applied. Undoubtedly, both substantive and procedural law rules for the regulation of silent settlement are necessary and indispensable. As for substantive law, it should be a well thought-out concept in which silence of administrative bodies in handling matters could be applied without affecting the public interest or the interests the applicant, or any other party to the proceedings. On the other hand, procedural regulations are to guarantee the protection of the rights administered against the inactivity or lack of action by administrative bodies, or lengthy and protracting proceedings.

Therefore, the legislator should ensure a well-considered qualification of cases to be recognised in a simplified manner, as well as adopt specific provisions that give competence to administrative bodies to settle matters tacitly so that the institution accomplishes the intended objectives of administrative improvement, and at the same time does not violate the procedural rights and guarantees of the parties for whom silence has legal effects.

Keywords: administrative silence - fictitious adjudication - inaction of administration 